Historic, Archive Document

Do not assume content reflects current scientific knowledge, policies, or practices. 



\title{
How to Build Up and Main
The Virgin Fertility of Our Soils
}

\author{
By \\ GEORGE W. CARVER, M. S. IN AGR-, D. SC. \\ Director
}


Tuskegee Institute Press-1936 


\title{
HOW TO BUILD UP AND MAINTAIN THE VIRGIN FERTILITY OF OUR SOILS
}

\author{
By G. W. Carver, M. S. Agr., D. Sc.; Director
}

\section{Origin of Scientific Agriculture}

One is not only surprised but astonished to learn that less than a century and a half ago, agriculture was without a scientific working basis. Credit goes to the great German chemist, Justus von Liebig for starting this revolutionary movement. The following four laws which form the foundation of modern agricultural practice were fully established by Liebig and should be studied and mastered by everyone attempting to deal with the fertility of the soil:

1. A soil can be termed fertile only when it contains all the materials requisite or necessary for the nutrition of plants in the required quantity and in the proper form.

2. With every crop a portion of these ingredients are removed. A part of this portion is again added from the inexhaustible store of the atmosphere; another part is lost forever if not restored by man.

3. The fertility of the soil remains unchanged if all the ingredients of a crop are given back to the land. Such a restitution is effected by fertilizers.

4. The fertilizers produced in the course of husbandry are not sufficient to maintain permanently the fertility of a farm; they lack the constituents which are annually exported in the shape of grain, hay, milk, and live stock.

The above four laws of Liebig contain a clear statement of the principles underlying the use of fertilizers; but to understand their meaning with satisfactory clearness, we must know something more in detail about such subjects as the following:

(a) The constituents of plants.

(b) The materials which furnish plant food.

(c) The condition these materials must be in before the plant can use them.

(d) The constituents of soils.

(e) What forms and quantities of plant food to use on different soils and crops.

This bulletin is not intended for an exhaustive treatise on the use of fertilizers. It does attempt, however, to embody a sufficient number of basic principles, put in non-technical language and made sufficiently clear, so that every farmer can master the problems of "when, with what, and how shall I fertilize my crops in such a man- 
ner as to produce the maximum yield and do it with the least financial expense and the least injury to the soil."

\section{Simple Elements the Plant Must Have}

Liebig's exhaustive study of plants and their requirements established the fact that there are fourteen (14) simple substances called elements which every farm crop must have in the proper quantity and form before the crop in question can make a maximum yield.

These substances are: carbon, hydrogen, oxygen, potassium, nitrogen, sulphur, iron, phosphorus, chlorine, magnesium, sodium, calcium, silicon, and manganese. These elements must be combined with each other or other substances to render them water soluble or soluble in very weak acids.

\section{Water}

Every person who wishes to grow plants successfully must first realize that the most abundant ingredient of a living, healthy, growing plant is water. In many succulent vegetables such as turnips and lettuce there is as much as ninety per cent $(90 \%)$, which means that in every 100 pounds of said vegetables, 90 pounds is water. The water requirements of the crops listed below, as worked out by various Experiment Stations, should be carefully studied.

Snyder in his book on "Soils and Fertilizers" says that it takes from 275 to 375 pounds of water to produce a pound of dry matter in a grain crop, and that in order to produce an average acre of wheat, 350 tons of water are needed.

The amount of water required for the production of an average acre of various crops is as follows:

Av. amt. Wa.

$$
\text { Tons }
$$

Min. amt. Wa.

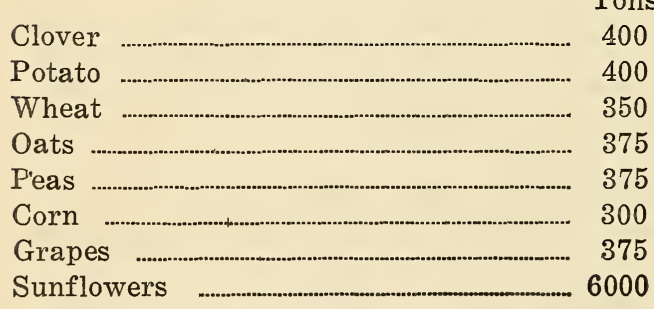

Tons

310

325

300

300

300

From the above table it is easy to see that growing crops must have large quantities of water and how very important it is for every farmer to know how to keep the amount of water in the soil needed by each crop. The soil loses the water of the greatest benefit to the crop by surface evaporation, so therefore, the practical thing is to learn how to save it. 


\section{How To Begin}

The first and absolutely the most important thing for every farmer to learn is that the physical condition of his soil is of greater importance than the chemical.

\section{Bad Physical Condition}

The land is in bad physical condition when it is:

(a) Badly washed and guttered.

Remedy: These ditches and gullies should be filled with pine tops, bark, leaves, and organic rubbish of any kind that will decay and ultimately make soil.

(b) Full of stumps, brush patches, briars, etc.

Remedy: All such should be cleaned up; dug out by the roots.

(c) Weedy, brushy, and broken down terraces; water logged soil; ditches that are not functioning.

Remedy: The terraces should be cleaned of the above weedy and brushy condition and put in repair. All ditches should be cleaned out and the wet places drained.

\section{The Seed Bed-Most Important}

After (a), (b) and (c) have been corrected you are ready for the most important of all soil operations, the one which determines the yield of fully one-half of the kind of crop we plant. If the seed bed is poorly prepared, no amount of after cultivation will give you the highest yield.

\section{Plowing}

In our soils here we recommend plowing from six (6) to eight (8) inches deep, using great care not to plow when the soil is too wet; this especially applies to heavy clay soils. It will ruin them physically by making brick mortar out of them.

\section{How Can I Tell When a Soil Is Too Wet?}

Possibly the oldest, simplest, and most effective test known is that of taking a handful of the soil and squeezing or rubbing it between the hands. If it sticks together or rolls up into a muddy ball, it is too wet to plow. If it falls apart when the hand is opened, you can plow it without injury.

\section{Cloddy Soil}

If possible do not break up into great clods. If this has to be done, put on the disc harrow, roller, drag, or any other form of clod masher and go over it in every direction until all the clods are mashed. Plowing it over the second time is often necessary if very cloddy; continue to pulverize until the soil is fine, loose, and mellow. Your soil is now in the best condition to absorb, retain, and furnish the growing plant with the kind of water it needs most. 


\section{How To Fertilize}

Before we can fertilize our crops intelligently we must master the few following basic facts which, all other things being equal, will insure every year against complete failure.

1. That all plants require food in order to live, grow, and mature.

2. That part of this food comes from the air and part from the soil as designated below.

$\begin{array}{cc}\text { Air Derived Elements } & \text { Soil } \\ \text { Nitrogen } & \text { Perived Elements } \\ \text { Oxygen } & \text { Phosphom } \\ \text { Hydrogen } & \text { Calcium } \\ \text { Carbon } & \text { Chlorine } \\ & \text { Sodium } \\ & \text { Sulphur } \\ & \text { Silicon } \\ & \text { Iron } \\ & \text { Manganese } \\ & \text { Magnesium }\end{array}$

3. That fully ninety per cent or more of our farm crops come from the air either directly or indirectly and not from the soil. The substances coming from the air are: sugars, fats, oils, gums, cellular matter, etc.

4. That all the above products are manufactured in the leaves of the plant, hence a good leaf growth is necessary for heavy crop production.

5. That our job is that of making conditions favorable for the plant to get all of these elements it can use.

6. That while the subject of plant food and fertilization has many complex angles, if the farmer will master the use of nitrogen, potash, and phosphoric acid, the others will come with comparative ease. We must understand these great truths.

7. That nitrogen has for its chief office the making of the roots, stems, leaves, and all the cellular matter of the plant.

8. That the chief office of potash seems to be that of making the sugars, fats, starches, gums, resins, oils, etc.

9. That phosphorus assists potash in the above compounds and in addition plumps and gives vitality to the seed.

\section{A Working Basis}

10. It is easy now for the farmer to see that he has a working basis for the proper fertilization of any crop he wishes to grow. 
11. That forage crops producing mainly leaves, stems, etc., as well as a number of truck garden crops will require liberal quantities of nitrogen; while grain crops will require liberal quantities of both potash and phosphorus.

\section{Where Plant Food Comes From}

12. That, roughly speaking, fertilizers may be divided into three classes, viz., natural, artificial, and indirect.

Natural, those we should be able to make on our farms, such as stable manure, refuse vegetables matter (composted), green crops plowed under, leaves from the forest, and muck from the swamp.

Artificial, the various commercial or chemical mixtures.

Indirect, those which are said to act as a stimulant such as lime, gypsum, salt, etc.

No fertilizer or system of fertilization to date has been found that will build up the land as effectively, cheaply, and permanently as farmyard manures.

Make Your Own Fertilizer on the Farm, Buy as Little as Possible

A year-round compost pile is absolutely essential and can be had with little labor and practically no cash outlay.

(a) Build one long bin or several smaller ones sufficient to hold a yearly supply.

(b) Spread two wagon-loads of muck and leaves over the bottom of the pen; then one load of barnyard manure; build up in this way until the pen is full.

(c) Put a rough shed over the pen to turn the bulk of the water from heavy rains, or mound up like a potato hill. This will prevent the excess of water from washing out the readily water-soluble fertilizing constituents.

(d) Put into this compost-heap all the wood ashes, old plaster, waste lime, rags, paper, and any other matter that will decay quickly. Bones beaten up fine are also excellent. If you cannot get the barnyard manure make the compost without it. You will be agreeably surprised at the increased yield of crops of all kinds. 
Composition of 1,000 Pounds of Fresh Excrements

\begin{tabular}{|c|c|c|c|c|}
\hline Animal & $\begin{array}{l}\text { Water } \\
\text { Pounds }\end{array}$ & $\begin{array}{l}\text { Ni'gen. } \\
\text { Pounds }\end{array}$ & $\begin{array}{l}\text { Phos. Acid } \\
\text { Pounds }\end{array}$ & $\begin{array}{l}\text { Alk. } \\
\text { Pounds }\end{array}$ \\
\hline Cow & ... 840 & 3.0 & 2.5 & 1.0 \\
\hline Hog . & 800 & 6.0 & 4.5 & 4.0 \\
\hline Sheep & 580 & 7.5 & 6.0 & 3.0 \\
\hline Horse $\quad . . . . . . . .$. & 760 & 5.0 & 3.5 & 3.0 \\
\hline 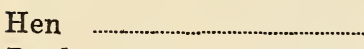 & 52.35 & 0.99 & 0.74 & 0.25 \\
\hline 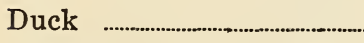 & 56.60 & 1.0 & 1.40 & 0.620 \\
\hline Goose & 77.10 & 0.55 & 0.54 & 0.95 \\
\hline
\end{tabular}

It is easy to see that our farm animals are great fertilizer factories, turning out the cheapest and best known product for the permanent building up of the soil. In addition to this farmyard manure, there are also many thousands of tons of the finest fertilizers going to waste all over the South, in the form of decaying leaves of the forest and the rich sediment of the swamp, known as "muck." Every idle moment should be put in gathering up these fertilizers.

Caution: Do not allow this compost-heap to become hot enough for steam to rise from it ("fire fang"), as you will lose much of the value of the manure. If the pile begins to heat and give off a strong odor, tear down at once and scatter dry earth, leaves, or something of this kind amongst it.

This method carefully planned and carried out will enable the farmer to have well rotted compost to use whenever needed by replenishing it with fresh material as fast as the old and well-rotted, is taken out.

Break land deep, if possible, ( 8 to 9 inches) and thoroughly; lay off rows with a middle-burster or two-horse plow; put compost in drill at the rate of 20 tons to the acre on medium land, and 25 tons to the acre on very poor land; plant directly on the fertilizer. Cultivate in the usual manner, bearing in mind:

(a) That clean cultivation is absolutely necessary. All weeds, grasses, and foreign plants should be cut up as they not only exhaust the water the crop should have, but the plant food as well.

(b) The dust mulch, which consists of finely pulverized soil (the finer the better) from two to three inches thick. The pulverizer should be run through the crop every eight or nine days during long hot, dry periods.

(c) Small areas in gardens, flower beds, trees, etc., can be mulched with straw, leaves, or coarse manure. 
The amount of Nitrogen, Phosphoric Acid, and Potash in Pounds Required for Each 1,000 Pounds of the Crops Given Below

(After Henry's Feeds and Feeding)

Fertilizer Constituents in 1,000 Lbs.

\begin{tabular}{|c|c|c|c|}
\hline Kind of Crop & Nitrogen & Phos. Acid & Potash Remarks \\
\hline Corn, Mixed .......... & Lbs. & $\begin{array}{l}\text { Lbs. } \\
7.0\end{array}$ & $\begin{array}{l}\text { Lbs. } \\
4.0\end{array}$ \\
\hline Corn Cobs & $\begin{array}{r}18.2 \\
5.0\end{array}$ & .6 & $\begin{array}{l}4.0 \\
6.0\end{array}$ \\
\hline Wheat & 23.6 & 7.9 & 5.0 \\
\hline Rye & 17.6 & 8.2 & 5.4 \\
\hline Oats & 20.6 & 8.2 & 6.2 \\
\hline Rice ……............. & 10.8 & 1.8 & 0.9 \\
\hline Millet & 20.4 & 8.5 & 3.6 \\
\hline Sorghum Seed & 14.8 & 8.1 & 4.2 \\
\hline Cotton Seed & 31.3 & 12.7 & 11.7 \\
\hline Cottonseed Meal & 67.9 & 28.8 & 8.7 \\
\hline Cottonseed Hulls & ... $\quad 6.9$ & 2.5 & 10.2 \\
\hline Sunflower Seed & ... 22.8 & 12.2 & 5.6 \\
\hline Peanut Meal & 75.6 & 13.1 & 15.0 \\
\hline Corn Stover & 10.4 & 2.9 & 14.0 Field Cured \\
\hline Mixed Grasses & 14.1 & 2.7 & 15.5 Air Dried \\
\hline Oat Straw & 6.2 & 2.0 & 12.4 \\
\hline Rye Straw & 4.6 & 2.8 & 7.9 \\
\hline Wheat Straw & 5.9 & 1.2 & 5.1 \\
\hline \multicolumn{4}{|l|}{ Legume Hay and Straw } \\
\hline Red Clover Medium .................. & 20.7 & 3.8 & 22.0 \\
\hline Red Clover Mammoth ............ & 22.3 & 5.5 & 12.2 \\
\hline Alsike Clover & 23.4 & 6.7 & 22.3 \\
\hline White Clover & 27.5 & 5.2 & 18.1 \\
\hline Crimson Clover & 20.5 & 4.0 & 13.1 \\
\hline Alfalfa & 21.9 & 5.1 & 16.8 \\
\hline Cow P'ea & 19.5 & 5.2 & 14.7 \\
\hline Soybean Straw & 17.5 & 4.0 & 13.2 \\
\hline \multicolumn{4}{|l|}{ Roots, Tubers, Etc. } \\
\hline Potato & 3.2 & 1.2 & 4.6 \\
\hline Beet Common & 2.4 & 0.9 & 4.4 \\
\hline Flat Turnip & 1.8 & 1.0 & 3.9 \\
\hline Rutabaga & 1.9 & 1.2 & 4.9 \\
\hline Carrot .......- & 1.5 & 0.9 & 5.1 \\
\hline Artichoke & 2.6 & 1.4 & 4.7 \\
\hline Cabbage & 3.8 & 1.1 & 4.3 \\
\hline Rape & 4.5 & 1.5 & 3.6 \\
\hline
\end{tabular}


The above table is sufficiently clear for every farmer to see with a considerable degree of accuracy the amounts of the three fertilizers he purchases every year that are removed from the soil. It also makes the second and third laws of Liebig more easily understood.

\section{Nitrogen}

Special attention is called to it here because it has characteristics not possessed by any of the other thirteen essential elements of plant growth, in so far as science has definitely established the facts. This is clear, however, that all plants bearing pods (known as legumes) have the power to take nitrogen from the air and give it to the soil, if the farmer will make conditions favorable for its development. All peas, beans, vetches, clovers, alfalfa, etc., belong to this group and are therefore nitrogen gatherers (soil builders).

In order to thrive these crops must have a generous supply of potassium, calcium, and phosphorus in the soil, together with the little organisms, (bacteria) which cause small swellings on the roots (nodules) which contain the bacteria that enable the plant to get its nitrogen from the air. Since this is true, it is not desirable to put large quantities of nitrogen in the soil for legumes.

If the farmer will study and put into effect the greatly abridged suggestions as set forth in this bulletin, he will be pleasantly surprised especially in the following directions:

1. The increase in the quantity and quality of his crops.

2. The almost unbelievably small amount of actual cash outlay required to do it.

3. The ease with which the planting, cultivating, and harvesting can be done.

4. And how the fertility of his land will increase from year to year with a corresponding increase in the value of his land. 